\title{
International Education for Enlightenment, for Opportunity and for Survival: Where Students, Migrants and Refugees Diverge
}

\author{
Bernhard Streitwieser \\ The George Washington University, United States \\ *Corresponding author: Email: streitwieser@gwu.edu \\ Address: Graduate School of Education and Human Development, The George Washington University, 2136 G Street NW, \\ Washington, DC 20052, United States
}

Received 2/12/19; revised 8/22/19; revised 9/1/19; accepted 9/15/19

We are all born equal, but we are not all

born with the same opportunities. Some will

be born to wealthy families, others will

struggle to make ends meet. Some will grow

up in an environment of conflict and

turmoil, and will face the challenges of

displacement and settling into a country

that is not their own, others will benefit

from a climate of social stability and

prosperity their whole lives.

—Angel Gurria, OECD 2018, p. 11

\section{Introduction}

In this article I make a simple observation I hope will encourage a more vigorous dialogue with additional evidence and examples to follow. I argue that participants in international education mobility fall into three broad and distinctly differentiated categories. By examining participants who study in a country other than their own in this manner, we can help educators not only understand who is participating in international education but also, we can begin to chart and recognize the needs of different students. This type of categorization has not yet been sufficiently analyzed in the extant literature in Comparative and International Education but needs to be.

The three categories that are the focus of this article are made up of different demographics of people according to their choices in engaging in international learning, also referred to as "educational mobility." Each categorization shows that student have different reasons to engage in educational mobility, different motivations, and different outcomes. They are made up of

1) those who voluntarily choose to study abroad as students and engage in "mobility for enlightenment;"

2) those who participate in education as economic migrants and seek "mobility for opportunity;"

3) those who want to begin or resume interrupted education as refugees who are engaging in "mobility for survival."

While there is some degree of overlap between each of these three groups, what distinguishes them needs to be studied in much greater detail. In the extant Comparative and International Education literature, the focus has so far primarily been on student populations that are engaging in international education for enlightenment. This has been to the detriment of studying the other two demographics, which are numerically much larger and who also participate in international education. Given the current global reality of increasing migrant and refugee flows (UNHCR 2018) and projections that these will continue to increase in the future, the higher education community has a humanitarian responsibility to also understand the needs of these populations and as such to craft innovative responses. To date, that response has been grossly inadequate (Streitwieser 2019; Streitwieser and Madden 2019).

Scholars have pointed out that international mobility trends and international migration patterns often mirror 
one another (Kondakci 2011; Li and Bray 2007; Mazzarol and Soutar 2002; McMahon 1992). Khalid Arar, Yassar Kondakci and Bernhard Streitwieser argue in the preface to their upcoming special issue of the journal, Higher Education Policy, that patterns of international student mobility and international migration are each built around geographical proximity, economic factors, and ethnic and historical ties. However, studies of mobility and studies of migration have been too isolated from one another so far to meaningfully impact scholarship and practice.

Today, there are unpreceded numbers of displaced people, migrants, and refugees traversing the globe. The children among them will need a way to continue their primary and secondary educations; the youth among them may seek higher education opportunity; and the adults may search for lifelong learning opportunities. These demographics are all on the move, outside of their countries of origin, and now make up a staggering 70.8 million, the largest number recorded since World War II (UNHCR n.d). I propose that we can count them among those who are engaging in so-called international education. Traditionally they have not been counted. This matters not only because refugees and migrants unfortunately make up such a large and growing global demographic, but also because we must be wholistic in our understanding of all who learn in settings other than their home countries, whatever their reasons may be. We need to move out of the comfort of only thinking of "international education" as a voluntary activity, but also realize it is forced upon increasing numbers of people around the globe (Ergin, deWit and Leask 2019).

\section{Participants in international education fall into three broad but distinct groupings}

Participants in education abroad are as vast as the challenges facing higher education institutions today. However, the activities of higher educational institutions and the clientele that attend them are only the smallest and most visible constituency engaging in international education. In reality, there are categories that differentiate the various participants engaging in international education, and they are driven by vastly differing realities that reveal distinct motivations, modes of engagement, and ultimately outcomes. These distinct groupings, while not entirely impermeable and sometimes on the borderline or a mixture of several, fall into what can be broken down into three generally distinguishable categories: mobility for Enlightenment, mobility for Opportunity, and mobility for Survival. These are illustrated in the table below. 
Table 1: Three distinct patterns of mobility

\begin{tabular}{|c|c|}
\hline 3 Types of 'Mobilities & Push and Pull Factors \\
\hline $\begin{array}{l}\text { Mobility for ...enlightenment } \\
\text { Study Abroad students (elite) } \\
\text { Ex. Americans to Europe, Germans to UK }\end{array}$ & $\begin{array}{l}\text { Broaden Horizons } \\
\text { Build relations } \\
\text { 'Horizontal mobility' } \\
\text { Mutual benefit to participant and host }\end{array}$ \\
\hline $\begin{array}{l}\text { Mobility for ...opportunity } \\
\text { Educational brain-drain, in some cases } \\
\text { Economic migrants } \\
\text { Full degree seeking students } \\
\text { Ex. Southern and Eastern Europeans to } \\
\text { Germany; Latin Americans to the US }\end{array}$ & $\begin{array}{l}\text { Pursue economic and educational } \\
\text { opportunities } \\
\text { Find better work and education } \\
\text { 'Vertical mobility' } \\
\text { Skilled and unskilled migration }\end{array}$ \\
\hline $\begin{array}{l}\text { Mobility for ...survival } \\
\text { Refugees } \\
\text { Ex. MENA, others to Europe }\end{array}$ & $\begin{array}{l}\text { Forced exit } \\
\text { Leave home or face death } \\
\text { Desperate escape } \\
\text { Welcome culture depends upon host country }\end{array}$ \\
\hline
\end{tabular}

\section{Group 1. Mobility for Enlightenment}

The first category, Mobility for Enlightenment, constitutes the smallest group, and is made up primarily of students of university age who are engaging in traditional education abroad. These students, with very few exceptions, represent what are regarded to be the elites of their society because of their resources (King, Findlay, Ahrens and Dunne 2011). There is also a much smaller sub-population of students of all ages who attend community colleges and global counterparts who also engage in traditional education abroad, but who represent nontraditional student populations (Raby and Valeau 2018) Mobility for enlightenment represents a voluntary educational enrichment for participants and a money maker for host countries. In addition, "studying abroad has become a key differentiating experience for young adults enrolled in tertiary education." (OECD 2018, p. 218). In the United States during the 2016/17 academic year 332,727 Americans studied abroad for academic credit, and one in 10 U.S. students generally studies abroad during their undergraduate career. This is a relatively small number. These students, with some notable exceptions (for example those at community colleges) have the means to spend time away from home and family and spread their wings to broaden their personal and intellectual horizons through travel and taking courses outside of their institution's home curriculum. There are of course exceptions to this: while it is easier for wealthier and traditional age students to study abroad, small numbers of those who are less wellresourced and non-tradition or part-time due to work and family, also engage in mobility. But the overriding trend remains for study abroad to be an activity of a relatively small and socio-economically advantaged student demographic.

\section{Group 2. Mobility for Opportunity}

The second group, Mobility for Opportunity, is made up of economic migrants who, according to United Nations figures in 2015, account for roughly 244 million people worldwide who are living outside of their countries and seeking opportunities elsewhere (UNHCR n.d.), as well as full degree seeking students. According to the International Migration Report, different push factors cause people to move from their home countries. These include seeking better job opportunities, better education and eventually a higher quality of life. 
Additional push factors include civil conflict, war, poverty and a wide range of inequalities. Another factor is advancement in modes of travel, which have eased the mode, speed and cost of mobility for masses of people around the globe (International Migrant Report 2017).

The category of migrants includes globally mobile degree seeking students who, according to the OECD's Education at a Glance report, account for 4.6 million students (OECD 2017). In a comparative scope, there is a difference between general economic migrants, who may face significant hardship if they do not migrate, and educational migrants, who are comfortable economically in their home countries, but have restricted educational opportunities. Within this group there is even a small but growing number of Americans seeking more affordable university degrees abroad, for instance in Germany's tuition free system. Thus, economic migrants are also participants in international education who have chosen to leave their home countries in search of better opportunities, often for the benefit of their children, in better resourced countries that may provide them with greater education access. These families and their children, who make up a much larger segment than those enjoying mobility for enlightenment, are also engaging in education abroad, but differently from the more elite study abroad students. Some economic migrants are part of the global brain circulation of talent but also contribute to their country's brain drain problem.

\section{Group 3. Mobility for Survival}

The third group, Mobility for Survival, are those who are engaging in mobility for no other reason than that they have been forced out of their home countries or regions to find a new safe haven elsewhere. Displaced persons and refugees are in this category and today account for 70.8 and 25.9 million inhabitants of the earth, respectively, who have been displaced within their home country or forced out of it because of civil war, natural disaster, political unrest, or being associated with an undesirable ethnic or religious group.

Data collected by the United Nations High Commissioner for Refugees (UNHCR) clearly indicates that mobility of school and university-age youth is not voluntary but sometimes in the case of forced resettlement becomes permanent. According to the
(OECD 2018), the development and maintenance of a cohesive society depends on its ability to integrate its newest members, such as immigrants, and to ensure that they have opportunities to develop the skills they need to contribute economically to their new communities. More than ever in the past, participation in higher education is a key to ensuring this development. Tragically, according to UNHCR figures, only $1 \%$ of refugees will manage to find their way into higher education (UNHCR 2016; UNHCR n.d.).

Refugee children will need K-12 education, along with teachers who are prepared to help them. Older students will yearn for access to a university and other forms of higher education. Many adults will want continuing education opportunities. Scholars at risk will want to resume their intellectual lives. So far, we have not had to think of international educational mobility in these terms, but displacement has now become a form of mobility that also requires us to respond as a globally enlightened education community. While developing cross-cultural understanding has always been a core component of mobility, the mobility of refugees and their needs compel us to also accept that we have an increasingly pressing moral obligation to help as we can.

\section{Discussion}

Students in the first category, Enlightenment, are seeking enlightenment through study abroad. Students in the second category, Opportunity, are also seeking enlightenment but are generally focused on finding opportunities that are not afforded to their social, racial, ethnic, or national constituency or group. The third category, Survival, also seeks enlightenment and opportunity but are not afforded these luxuries in their present condition and need to ensure their survival because their personal, social, cultural, and/or national situation is under dire threat.

One could see the first category as a subset of the second, and the second category as a subset of the third, which makes the third the most complex and explains why it is also the most challenging to address today. The underlying structure of these categories explains the complexity, challenge and urgency of the situation the 
globe is now facing. That urgency calls on the higher education enterprise to respond. If as enlightened educators we are intellectually privileged, that status also brings with it a responsibility to look beyond ourselves and to make opportunities possible for others if we can help them in any way.

As international educators today, we need to strategically contemplate how we can incorporate and enable a much larger tent of participants than we have in the past. The numbers provided by the UNHCR challenge higher education internationalization in a way we have not had to consider in previous decades. A newer, updated, and more inclusive view of international education and higher education needs to also account for students who come from at-risk migrant and refugee backgrounds. In the same way that we have needed to more successfully include people of color and firstgeneration students engaging in international education opportunity for enlightenment, we now must also consider refugees and migrants engaging in international education for opportunity and survival.

\section{Conclusion}

There are important structural differences between each of the three groups I have described in this essay. Perhaps most important are the contexts from which each of the students in these three types of mobility are coming. The Enlightenment group is defined in part by a home community that is generally in sync with its educational environment, which makes their motivation focused on seeking greater understanding, a wider worldview or perhaps a changed perspective, which are generally attributes ascribed to the notion of 'enlightenment.' For the Opportunity group, the home community is not in sync socially or economically, so the motivation has become to seek out opportunities that a new community can offer. For the Survival group, the home community has become horribly out of sync and is now dysfunctional, disruptive, threatening, and deadly, so the motivation is escape and survival. As educators, we need to figure out how we can help. It is an urgent calling we cannot ignore any longer.

\section{References}

Gurria, Angel. 2018. OECD, "Editorial - Education's Promise to All", in Education at a Glance 2018: OECD Indicators, OECD Publishing, Paris. Retrieved from: https://www.oecdilibrary.org/docserver/eag-2018-2en.pdf?expires $=1564688810 \& i d=i d \& a c$ cname $=$ gue st\&checksum=031AEC46B8C88052722B3663641 82FE9

Ergin, Hakan, de Wit, Hans, and Leask, Betty. 2019. "Forced Internationalization of Higher Education: An Emerging Phenomenon." International Higher Education, (97): 9-10.

https://doi.org/10.6017/ihe.2019.97.10939

King, Russell, Findlay, Allen, Ahrens, Jill, and Dunne, Mairead. 2011. "Reproducing Advantage: The Perspective of English School Leavers on Studying Abroad." Globalisation, Societies and Education, 9(2): 161-181.

Kondakci, Yassar. 2011. "Student Mobility Reviewed: Attraction and Satisfaction of International Students in Turkey." Higher Education, 62(5): 573-592.

Li, Mei, and Bray, Mark. 2007. "Cross-border Flows of Students for Higher Education: Push-Pull Factors and Motivations of Mainland Chinese Students in Hong Kong and Macau." Higher Education, 53(6): 791-818.

Mazzarol, Tim, and Soutar, Geoffrey. N. 2002. "Pushpull" Factors Influencing International Student Destination Choice." International Journal of Educational Management, 16(2): 82-90.

McMahon, Mary E. 1992. "Higher Education in a World Market: An Historical Look at the Global Context of International Study." Higher Education, 24: 465482.

Organization for Economic Co-operation and Development (OECD). Education at a Glance 2017: OECD Indicators. OECD: Paris: 2017. Retrieved from https://doi.org/10.1787/eag-2017en.

Organization for Economic Co-operation and Development (OECD). Education at a Glance 2018: OECD Indicators. Paris: OECD, 2018. 
Retrieved from https://doi.org/10.1787/eag-2018-

en.

Raby, Rosalind Latiner, and Edward J. Valeau, eds. Handbook of comparative studies on community colleges and global counterparts. Springer International Publishing, 2018.

Raby, Rosalind Latiner, and Edward J. Valeau, eds. Handbook of comparative studies on community colleges and global counterparts. Springer International Publishing, 2018.

Rivza, Baiba, and Ulrich Teichler. 2007. "The Changing Role of Student Mobility." Higher Education Policy 20.4 (2007): 457-475.

Streitwieser, Bernhard. 2019. "Why Migrants and Refugees Have a Place in International Education." NAFSA Trends \& Insights: Internationalization in a Time of Global Disruption, March: 1-14.

Streitwieser, Bernhard and Madden, Meggan. 2019. "On the Duty of Care: Refugees, At-Risk Migrants, and Internationalization." International Educator, May/June 2019. Washington, DC: NAFSA.

United Nations High Commissioner for Refugees (UNHCR) (N.d.). "Figures at a Glance." Retrieved from https://www.unhcr.org/en-us/figures-at-aglance.html 